\title{
食用アマランサスの抗酸化能と肉団子調製・保存における抗酸化効果
}

\section{A Study of the Food Functional Characteristics and Utilization of Amaranthus}

\author{
三宅 妙子* . 菅原 龍幸** \\ $(*$ 川崎医療福祉大学. **聖徳大学)
}

\author{
Taeko Miyake*, Tatsuyuki Sugahara** \\ *Kawasaki University of Medical Welfare, 288, Matsushima, Kurashiki-shi, Okayama, 701-0193 \\ **Seitoku University, 550, Iwase, Matsudo-shi, Chiba, 271-8555 \\ *テ701-0193 岡山県倉敷市松島 288 \\ **厂二271-8555 千葉県松戸市岩瀬 550
}

Amaranthus L. are edible plants that are rich in protein, dietary fiber, minerals and vitamins. There are 12 varieties which are cultivated and used in food preparations in Japan: Rarushaku, BAYAM.M, BAYAM.P, ABIEBIE, Maruba, Yanagiba, and Baiamu which belong to A. vegetables and Mexico, Nairobi, Nouken c. 91-3, K4, and Akou which belong to A. grains. Since the young stems and leaves of A. grains are used as vegetables. The objective of this study was to determine if edible amaranthus contains any natural antioxidant materials. 17 samples, 12 leaves and five grains, were screened using ethanol extracts in a methyl linoleate oil system. Fifteen of the samples contained rather strong antioxidant activity.

The results were as follows: 1) Seven samples had strong antioxidant activities: water extracts of the leaves of ABIEBIE, Yanagiba, and Nairobi, ethanol extracts of the leaves of BAYAM.M and ABIEBIE, and ether extracts of the leaves of Baiamu and Nairobi.

2) Water extracts of ABIEBIE and Yanagiba leaves showed a synergistic antioxidant effect with citric acid, and water extracts of ABIEBIE and Yanagiba leaves and ethanol extract of ABIEBIE leaves showed a synergistic antioxidant effect with $\alpha$-tocopherol.

3) Water extracts of ABIEBIE and Yanagiba leaves were stable against heat treatment at $100^{\circ} \mathrm{C}$ for $2 \mathrm{~h}$. 4) Water extracts of ABIEBIE, Yanagiba, and Nairobi leaves were stable at pH's 3.0,5.0,7.0, and 9.0.5) Water extracts of ABIEBIE and Yanagiba leaves showed activity with a minced pork model system. The synergistic antioxidant effect with the addition of citric acid or $\alpha$-tocopherol showed a stronger antioxidant activity. 6) The HPLC (High Performance Liquid Cromatography)method for evaluation of the free radical-scavenging activity of foods, using 1, 1-Dipheny1-2-picrylhydrazyl, was used in 13 samples. Eight samples showed free radical-scavenging activity. Three of these, water extracts of ABIEBIE, Yanagiba and Nairobi leaves, showed the particularly strong free radical-scavenging activity. In conclusion, water extracts of edible amaranthus have natural antioxidants. 


\section{はじめに}

アマランサス (Amaranthus L.) は, 食品栄養学的に も優れた食用作物として期待されるアカザ目, ヒユ科ヒ

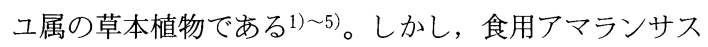
の抗酸化性など三次機能についての研究はほとんどみら れないようである。そこで今回著者らは, 食用アマラン サスが抗酸化能を有するか否かのスクリーニングを行 (6) 8), 津田らの実験方法 ${ }^{9,10)}$ を参考に, 13種の食用ア マランサス抽出物に対して抗酸化性を重ねて確認すると 共に, 天然抗酸化㓮であるクエン酸, $\alpha$-トコフェロー ルとの相乗効果, 食用アマランサス抽出物の熱や $\mathrm{pH}$ に 対する安定性について試験し, さらにDPPH（1,1-シ フェニル-2-ピクリルヒドラジル）を用いたラジカル捕 捉活性試験 ${ }^{11)}$ も試みた。そして著明な抗酸化効果が認め られた試料については, 肉団子調製時に抽出物を添加し, 保存中の抗酸化性を油脂の変敗度を指標として検討し た。

\section{実験方法}

\section{1. 試料}

試料は財農産業振興奨励会から入手した種子を用いて 栽培したものである。種類については, 野菜用のラルシ ヤーク, バヤム・エム, バヤム・ピイ, アビエビエ, 丸 葉, 柳葉, バイアムの 7 種と, 子実用では, $A$. hypochondriacus に属するメキシコ, ナイロビ, 農研セ 91-3と, A. caudatus に属するK 4 と赤穂の 5 種, 計 12 種 である。これらは，1996年から1997年に岡山県のアマラ ンサス生産地の賀陽町の農家にて栽培し, 適期に収穫し た ${ }^{12,13)}$ 。子実用 5 種については子実を 8 月下旬に, 茥葉 を6月下旬に収穫したものを用いた。

野菜等の茎葉は凍結乾燥し, 子実は, 穂を収穫後10日 前後温室内にて自然乾燥させた後, 唐箕を用いて子実を 分別収集し, 夾雑物を除去するために水洗し, $35 \sim 40{ }^{\circ} \mathrm{C}$ で一晚乾燥したものを粉砕して試料とした。

\section{2. 抽出物等の調製法}

(1)抗酸化能のスクリーニング用抽出物の調製 試料 粉末 $1 \mathrm{~g}$ に $20 \mathrm{ml}$ のエタノールを加え, 一晚室温にて放 置後, 5,000rpmで15分遠心分離し, その上澄液を抽出 液とした。

(2)抗酸化力の測定用抽出物の調製 水抽出: 試料 （アビエビエ, 柳葉, ナイロビと $\mathrm{K} 4$ の茥葉） $15 \mathrm{~g}$ に水 $400 \mathrm{~m} l$ を加えてホモジナイズし, $100^{\circ} \mathrm{C}$ の湯浴上で30分 間加熱還流後, 万過し, 万液を得た。抽出残渣は更に水
$200 \mathrm{~m} l$ を加え同様の方法で 1 回抽出し，万液を合わせて 濃縮後, 全量を $100 \mathrm{~m} l$ とした。

エタノール抽出10): 試料 (バヤム・エム, アビエビエ, 柳葉,バイアム, メキシコの茥葉） $15 \mathrm{~g}$ に $99.5 \%$ エタノー ル $250 \mathrm{~m} l$ を加えてホモジナイズし, 一晚冷蔵にて放置後, ろ過し，ろ液を得た。抽出残渣は更に $99.5 \%$ エタノール $125 \mathrm{~m} l$ を加え同様の方法で 1 回抽出し，ろ液を合わせて 濃縮後, 全量を $100 \mathrm{~m} l$ とした。

エーテル抽出 : 試料（バイアムとナイロビ，農研セ91 -3，K4それぞれの茥葉） $15 \mathrm{~g}$ にジエチルエーテル $250 \mathrm{~m} l$ を加えてホモジナイズし, 一晚冷蔵にて放置後, ろ過し, ろ液を得た。抽出残渣は更にジエチルエーテル $125 \mathrm{~m} l$ を 加え同様の方法で 1 回抽出し，ろ液を合わせた。ろ液中 のジエチルエーテルは,ソックスレー抽出器にて回収し, 抽出物は濃縮乾固後, $99.5 \%$ エタノールに溶解して全量 を $100 \mathrm{ml}$ とした。

(3)肉団子の調製肉団子の配合割合は, 内藤らの方 法14)を参考に豚ロースのミンチ $150 \mathrm{~g}$ ，馬鈴薯デンプン $25 \mathrm{~g}$, 䳕卵 $20 \mathrm{~g}$, 蒸留水 $5 \mathrm{~g}$ を基本配合とし 1 個 $20 \mathrm{~g}$ の肉 団子を調製した。材料はいずれも市販品を用い, アマラ ンサス抽出液を添加する場合は, 蒸留水と代替えした。 保存条件は $2{ }^{\circ} \mathrm{C}$ と, 加熱条件はガス高速レンジコンベ ック（リンナイ侏RCK-10 E-10, 消費電力 $90 \mathrm{~W}$ ）で200 ${ }^{\circ} \mathrm{C} 2$ 分間, 次いで $180^{\circ} \mathrm{C} 5$ 分間加熱した。

\section{3. 試薬}

抗酸化能測定のためのリノール酸メチルは東京化成工 業秼の一級品, リノール酸は和光純薬侏製を使用し, 抗 酸化剂としてAldrich Chem.侏Trolox を使用した。

\section{4. 抗酸化力の測定}

(1)抗酸化能のスクリーニング I 能勢(6), 春日ら ${ }^{7,8)}$ の方法に従い, 小試験管に採ったリノール酸メチル 100 $\mu l$ に, 抽出液 $50 \mu l$ を加え, $50{ }^{\circ} \mathrm{C}$ で25時間反応後, Lea 法の改良法 ${ }^{6,15)} に よ り$ 過酸化物価 (POV) を測定した。 抗酸化の判定は, 抽出液添加区のPOV $\left(\mathrm{POV}_{\mathrm{s}}\right)$ と, 抽 出液に代えてエタノールを添加したコントロール区の $\mathrm{POV}\left(\mathrm{POV}_{\mathrm{c}}\right)$ の比を求めることにより行った。

(2)抗酸化能のスクリーニング II 10) リノール酸を基 質としたモデル系（以後リノール酸モデル系とする）を 用いて検討した。標準反応液は, リノール酸 $0.13 \mathrm{~m} l$, $\mathrm{pH} 7.0,50 \mathrm{mM}$ リン酸緩衝液 $10 \mathrm{~m} l, 99.5 \%$ エタノール $10 \mathrm{~m} l$ を混合した溶液に, 蒸留水を加えて $25 \mathrm{~m} l$ とした。 アマランサス抽出液添加の反応液は, 抽出液の添加量が 乾燥試料として反応液のそれぞれ0.1，0.2，0.4，0.6, $0.8 \%$ 混合されるように, 蒸留水または $99.5 \%$ エタノー 
ルと代替えして添加した。これらの反応液は, 共栓付 $100 \mathrm{~m} l$ 容褐色広口瓶に移し， $40^{\circ} \mathrm{C}$ のインュュ゙ーターに 遮光保存した。保存期間中，1 日抢きに酸化の度合いを ロダン鉄法16)によりPOVを，Griewhan 法17)により TBA 価を測定した。

(3)クェン酸, $a$-トコフェロールの相乗効果 ${ }^{10)}$ の抗酸化能のスクリーニングの結果, 特に強い抗酸化効 果を示したアマランサス抽出液 7 種について, リノール 酸モデル系において，アマランサス抽出液とクエン酸ま たは $\alpha$ ートコフェロールを混合し，これらの相乗効果を 測定した。リノール酸モデル系への食用アマランサス抽 出液の添加量は, 乾燥試料として反応液のそれぞれ 0.1 , $0.2 ， 0.4 \%$ とし，クエン酸は $40 \mu \mathrm{g} / \mathrm{ml}$ を $0.5 \mathrm{ml}(0.08 \%$ に相当), $\alpha$-トコフェロールは $20 \mu g / \mathrm{m} l$ を $0.5 \mathrm{~m} l(0.04$ \%に相当)，いずれも蒸留水または $99.5 \%$ エタノールと 代替えして添加した。

(4)アマランサス抽出物の熱安定性 ${ }^{10)}$ リノール酸モ デル系に, (3)と同様のアマランサス抽出液を加熱処理し て添加し, 反応液を調製した。アマランサス抽出液は, 沸騰水浴中に $0,30,90,120$ 分間保持し, 各保持時間後 直ちに氷冷したもので, 抽出液の添加量は, 乾燥試料と して反応液のそれぞれ0.1，0.2，0.4\%とし，いずれも 蒸留水または $99.5 \%$ エタノールと代替えして添加した。 結果は, 未加熱試料の抗酸化性を $100 \%$ とした時の各熱 処理試料の抗酸化性で表した。

(5)アマランサス抽出物の $\mathrm{pH}$ 安定性 ${ }^{10)}$ リノール酸 モデル系に, (3) と同様のアマランサス抽出液を各 $\mathrm{pH}$ 緩 衝液 $10 \mathrm{~m} l$ に溶解して加熱処理したものを添加し, 反応 液を調製した。pH緩衝液は, $\mathrm{pH} 3.0$ と p 5.0 の $50 \mathrm{mM}$ 酢酸緩衝液, $\mathrm{pH} 7.0$ の $50 \mathrm{mM}$ リン酸緩衝液, $\mathrm{pH} 9.0$ 950 mM グリシン緩衝液を用い, 沸騰水浴中に 120 分間保持し, 直ちに氷冷したもので, 抽出液の添加 量は, 乾燥試料として反応液のそれぞれ $0,1,0.2,0.4$ \%とし，いずれも蒸留水または $99.5 \%$ エタノールと代替 えして添加した。結果は $\mathrm{pH} 7.0$ の未加熱試料の抗酸化 性を $100 \%$ とした時の各熱処理試料の抗酸化性で表した。 なお, (3)(4)(5)の抗酸化力の測定方法は, (2) と同様にし た。

(6)ラジカル捕捉活性試験18) $\quad 0.5 \mathrm{mMDPPH}\left(1,1^{-}\right.$ ジフェニル-2-ピクリルヒドラジル）エタノール溶液 1 $\mathrm{m} l$ に, pH 7.4, 100 mMTris-HCl 緩衝液 $800 \mu l$ と500 $\mu$ MTrolox エタノール溶液または試料溶液 $200 \mu l$ を加え て混和後, 室温で暗所にて20分間反応させた。分析は, 高速液体クロマトグラフを使用し, 送液ポンプに日立 $\mathrm{L}$
-6,300, 検出器に日立 L-4,250を用いた。測定条件は, カラムに日立 $\mathrm{L}-5,025 （ \mathrm{C} 84.6 \mathrm{~mm} \phi \times 150 \mathrm{~mm}$ ）を用 い, カラム温度 $20^{\circ} \mathrm{C}$, 流速 $1.0 \mathrm{~m} l / \mathrm{min}$, 移動相は, $70 \%$ メタノール溶液で分析した。検出は $517 \mathrm{~nm}, \mathrm{DPPH} の$ 保持時間は8.5分であり, データ処理はクロマトデータ 処理（日立 D-2,500）で行った。

\section{(7)肉団子の油脂の酸化抑制度の測定}

1) 脂質の抽出および測定: 各肉団子の脂質の抽出 はクロロホルム・メタノール混液 (CM 混液)改良抽出法 ${ }^{19)}$ に従った。

2 ) 油脂の変敗度測定 : 油脂の酸化安定性の指標々 して, Lea 法の改良法6,15)により, 過酸化物価（POV） を測定した。

\section{結果}

\section{1. 食用アマランサスの抗酸化能のスクリーニング $\mathrm{I}$}

リノール酸メチル $1 \mathrm{~m} l$ あたり, 乾燥試料 $0.025 \mathrm{~g}$ 相当 量のエタノール抽出物を加えて行った抗酸化能スクリー ニングの結果を Table 1 に示した。試料抽出液添加区の 過酸化物価 $\left(\mathrm{POV}_{\mathrm{s}}\right)$ とコントロール区の過酸化物価 $\left(\mathrm{POV}_{\mathrm{c}}\right)$ の比 $\mathrm{POV}_{\mathrm{s}} / \mathrm{POV}_{\mathrm{c}}$ によって抗酸化効果を 4 段階 に区分けした。すなわち，抗酸化性の著明なものを++： $0 \leqq \mathrm{POV}_{\mathrm{s}} / \mathrm{POV}_{\mathrm{c}}<0.2$, 抗酸化活性の強いものを+ :

Table 1 Screening for antioxidant activity of edible amaranthus

\begin{tabular}{lc}
\hline \multicolumn{1}{c}{ Variety } & Activity \\
\hline Rarushaku (A) & ++ \\
BAYAM.M (A) & ++ \\
BAYAM.P (A) & ++ \\
ABIEBIE (A) & ++ \\
Maruba (A) & ++ \\
Yanagiba (A) & ++ \\
Baiamu (A) & ++ \\
Mexico (A) & ++ \\
Nairobi (A) & ++ \\
Nouken c.91-3 (A) & ++ \\
K4 (A) & ++ \\
Akou (A) & ++ \\
Mexico (B) & ++ \\
Nairobi (B) & ++ \\
Nouken c.91-3 (B) & - \\
K4 (B) & ++ \\
Akou (B) & - \\
\hline
\end{tabular}

(1) Tissues of plant body used for extraction are indicate as follows: A; Stems \& Leaves $B$; Seeds

(2) $++: 0 \leqq \mathrm{POV}_{\mathrm{s}} / \mathrm{POV}_{\mathrm{c}}<0.2+: 0.2 \leqq \mathrm{POV}_{\mathrm{s}} / \mathrm{POV}_{\mathrm{c}}<0.4$ $\pm: 0.4 \leqq \mathrm{POV}_{\mathrm{s}} / \mathrm{POV}<0.7 \quad-: 0.7 \leqq \mathrm{POV}_{\mathrm{s}} / \mathrm{POV}_{\mathrm{c}}$

$\mathrm{POV}_{\mathrm{s}}$ : Peroxide value with sample

$\mathrm{POV}_{c}$ : Peroxide value of control 


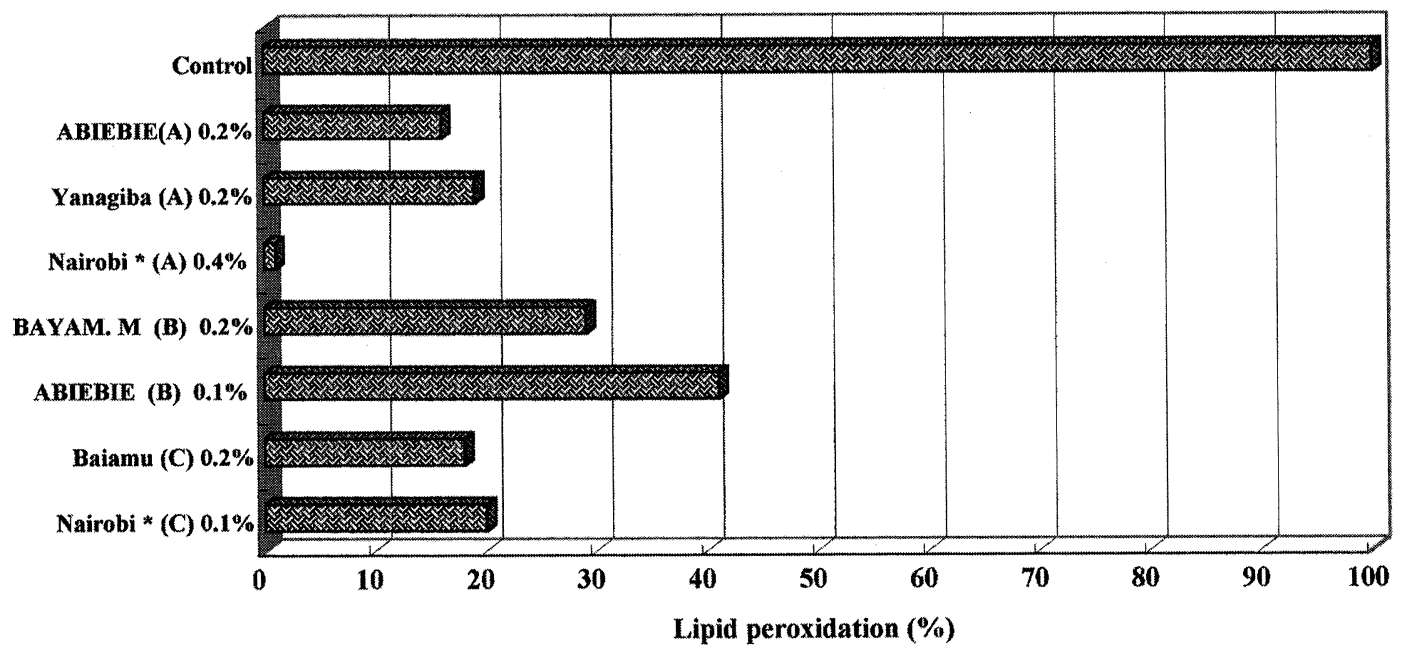

Fig.1 Antioxidant activity of crude extract prepared from edible amaranthus as measured by thiocyanate method after incubation for 7 days

*: Stems \& Leaves $\quad$ A: water extract $\quad$ B: ethanol extract $\quad$ C:ether extract

$0.2 \leqq \mathrm{POV}_{\mathrm{s}} / \mathrm{POV}_{\mathrm{c}}<0.4$, 抗酸化活性の弱いものを \pm :

$0.4 \leqq \mathrm{POV}_{\mathrm{s}} / \mathrm{POV}_{\mathrm{c}}<0.7$, 抗酸化活性のないものを一：

$0.7 \leqq \mathrm{POV}_{\mathrm{s}} / \mathrm{POV}_{\mathrm{c}}$ とした。

このスクリーニングの結果, 試験した食用アマランサ スのエタノール抽出液は, リノール酸メチルの POVの 上昇を抑制する効果を15部位が有していることを示し た。そして，その効果はすべて $\mathrm{POV}_{\mathrm{s}} / \mathrm{POV}_{\mathrm{c}}$ が++であ
り,かなり強い抗酸化能の存在が示唆された。

2. 食用アマランサスの抗酸化能のスクリーニング II アマランサス抽出物のリノール酸モデル系における， ロダン鉄法を用いた抗酸化試験で, 特に強い抗酸化効果 を示した 7 種たけを Fig.1に示した。結果は, 測定期間 中 7 日目にコントロールの吸光度がほぼ最大になったの で, この時のコントロールの吸光度を 100 とし, アマラ

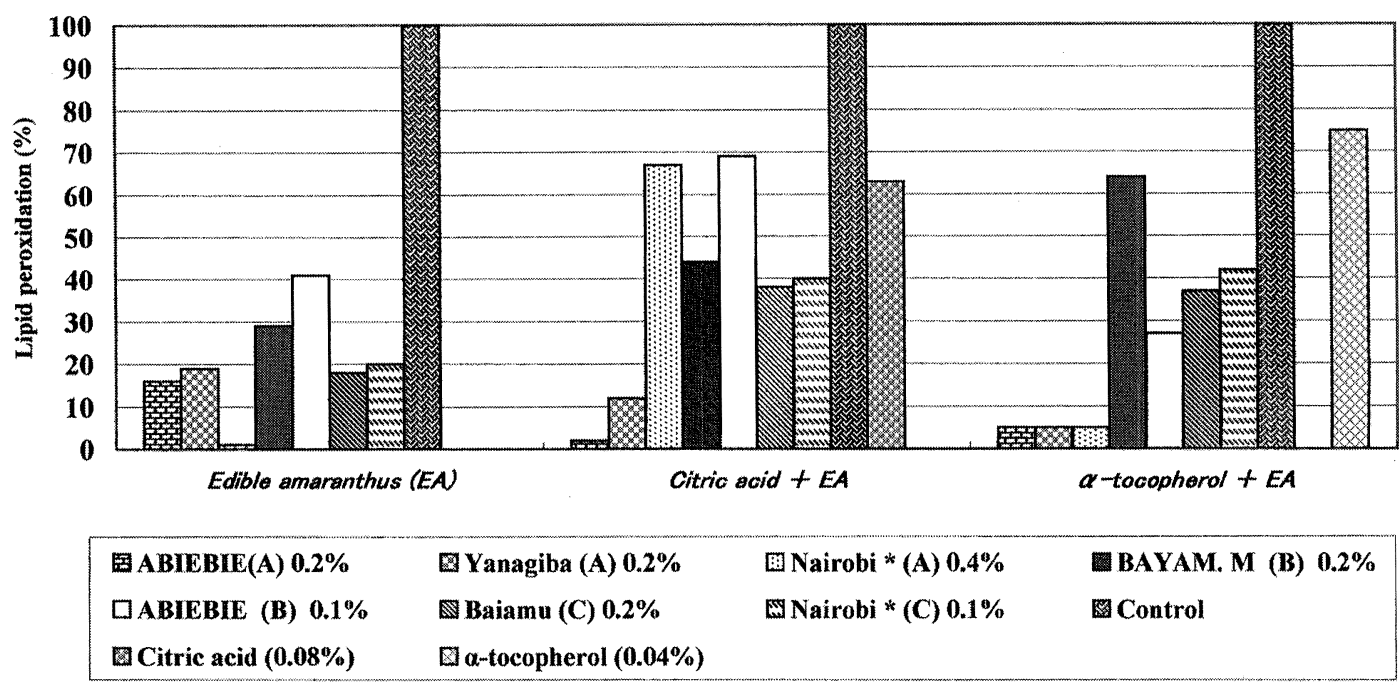

Fig.2 Synergetic antioxidant activity of edible amaranthus extract with citric acid or $\alpha$-tocopherol as measured by thiocyanate method after incubation for 7 days
* : Stems \& Leaves
A: water extract
B: ethanol extract
C: ether extract 


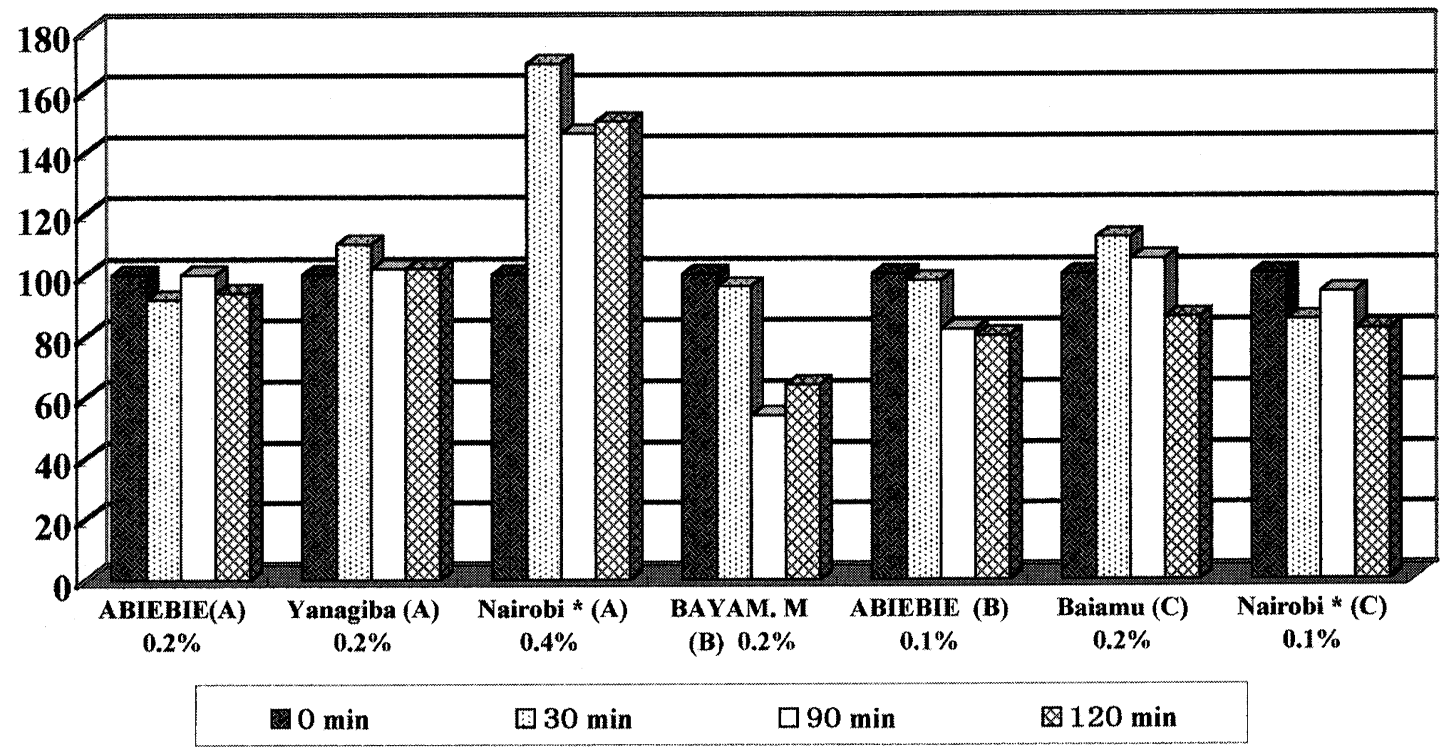

Fig.3 Effect of heat treatment on antioxidant activity of edible amaranthus extract as measured by thiocyanate method * : Stems \& Leaves A: water extract B: ethanol extract $\quad$ C: ether extract

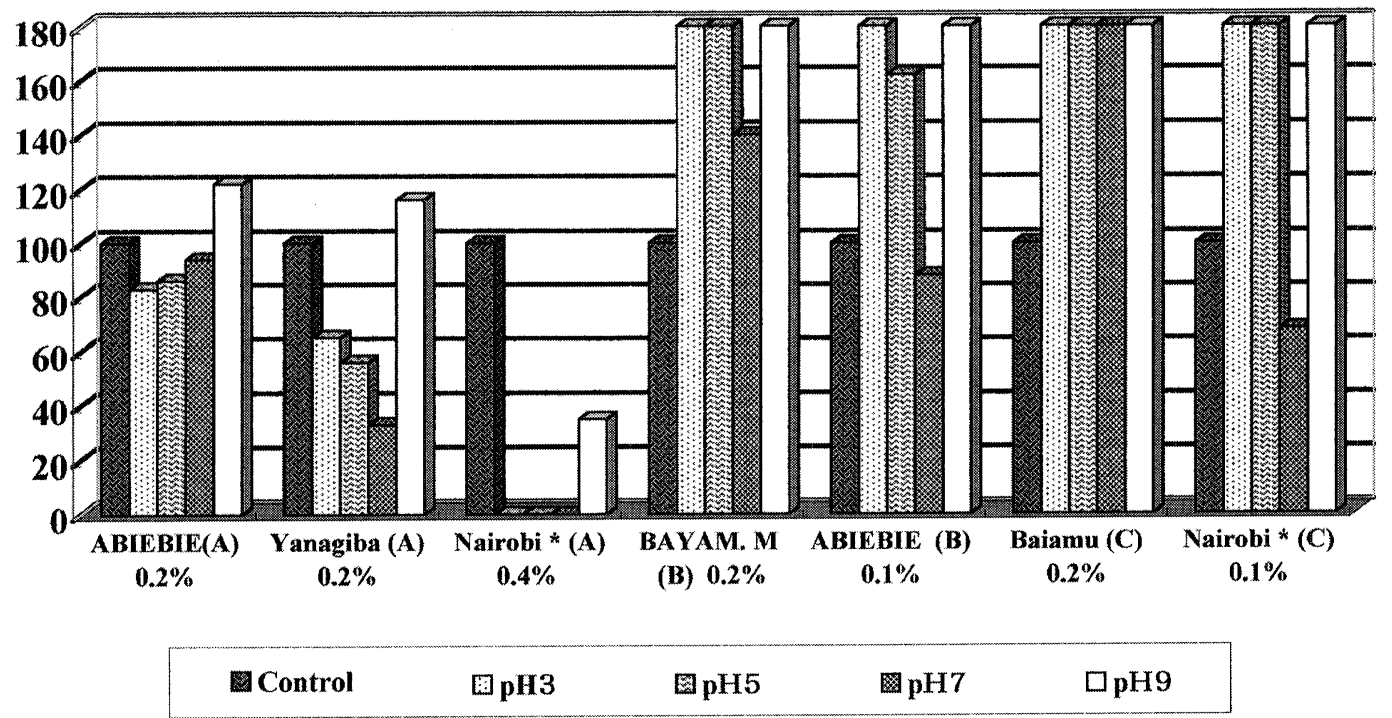

Fig.4 Effect of pH on antioxidant activity of edible amaranthus extract as measured by thiocyanate method * : Stems \& Leaves $\quad$ A: water extract $\quad$ B: ethanol extract $\quad$ C: ether extract

ンサス抽出物添加時の脂質の過酸化度を示した。水抽出 物では, アビエビエ $0.2 \%$ 添加が 16 , 柳葉 $0.2 \%$ 添加が 18 , ナイロビ茎葉 $0.4 \%$ 添加が 1 , エタノール抽出物では, バヤム・エム $0.2 \%$ 添加が 28 , アビエビエ $0.1 \%$ 添加が 40 ,
エーテル抽出物ではバイアム $0.2 \%$ 添加が 18 , ナイロビ 茥葉 $0.1 \%$ 添加が 19 を示した。

3. クェン酸, $a$-トコフェロールとの相乗効果

リノール酸モデル系に拈ける, アマランサス抽出物と 


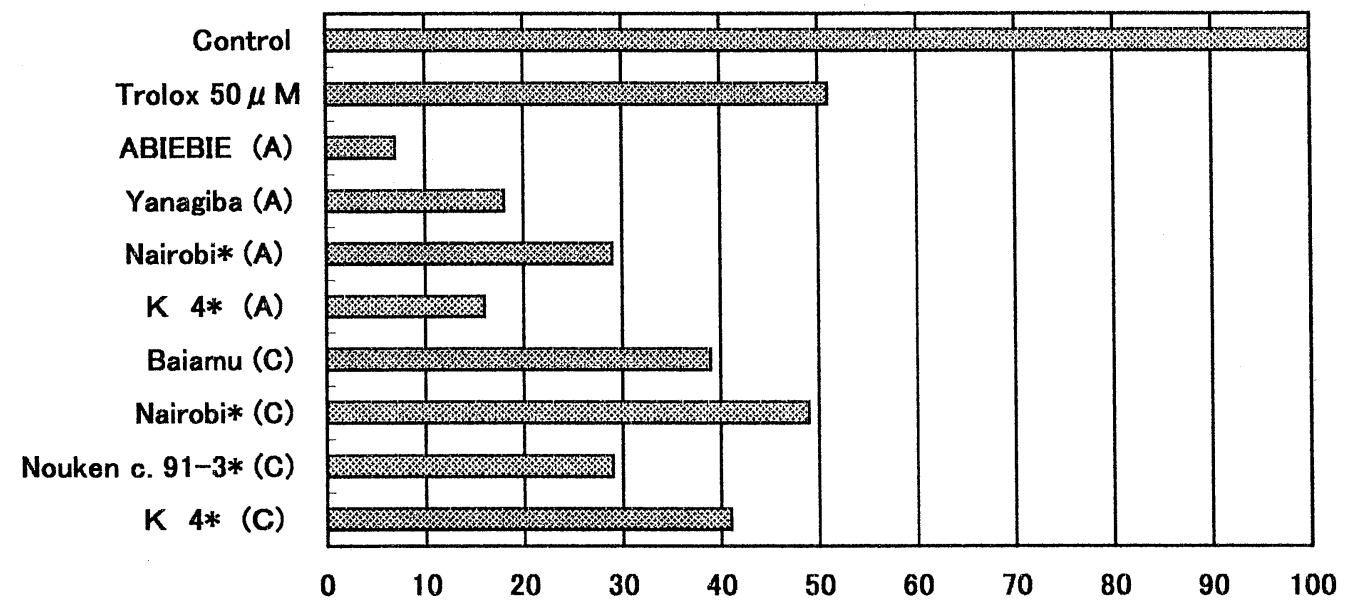

Fig.5 Radical-scavenging activity of crude extract prepared from edible amaranthus as measured by the DPPH-HPLC method
* : Stems \& Leaves
A: water extract
C: ether extract

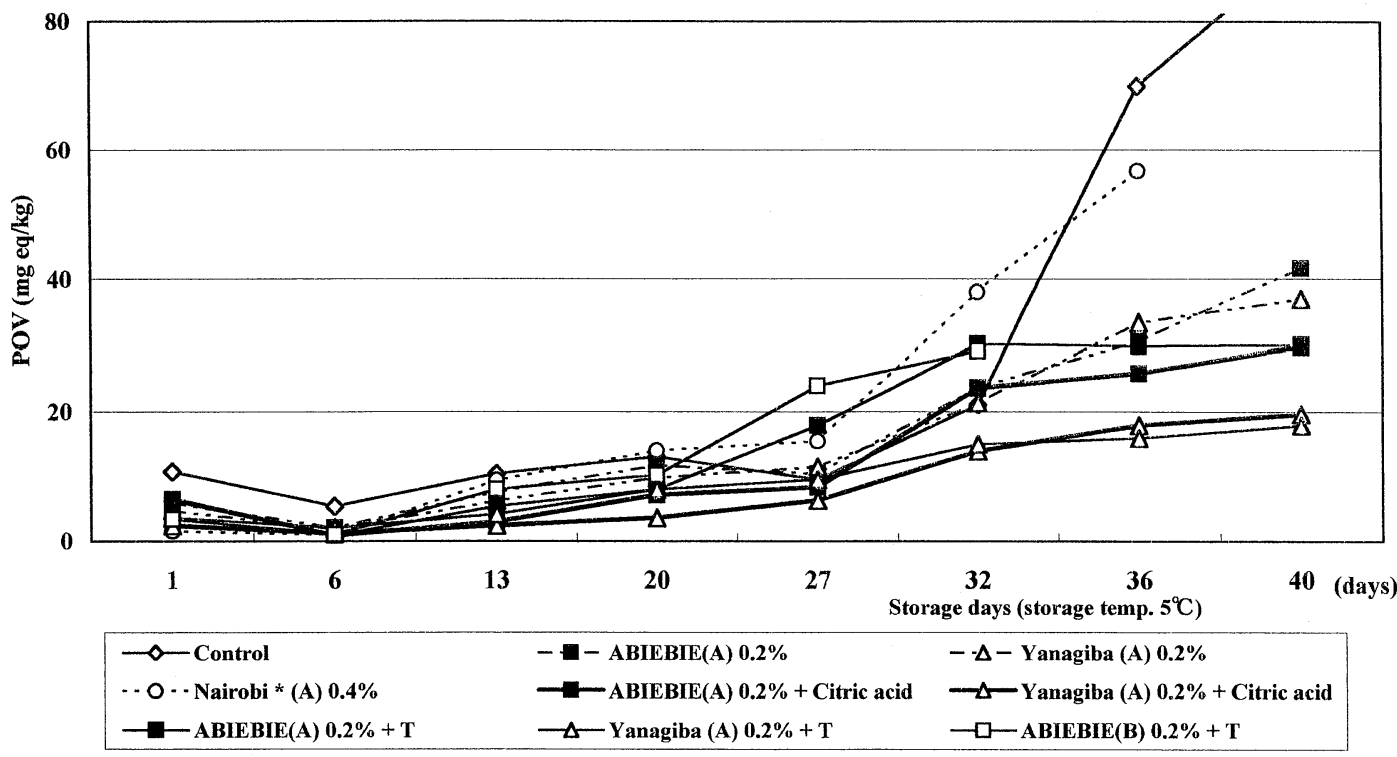

Fig.6 Antioxidant activity of edible amaranthus extract with a minced pork model systme POV: Peroxide value * : Stems \& Leaves A: water extract $\quad$ B: ethanol extract T: $\alpha$-tocopherol

クエン酸， $\alpha$-トコフェロールとの相乗効果についての ロダン鉄法による測定結果を Fig.2 に示した。クエン酸 とは, アビエビエと柳葉の水抽出物が相乗効果を示し, $\alpha$-トコフェロールとは, アビエビエと柳葉の水抽出物, アビエビエのエタノール抽出物が相乗効果を示した。

\section{4.アマランサス抽出物の熱安定性}

アマランサス抽出物の各温度における抗酸化力の安定
性について，ロダン鉄法による測定結果を Fig. 3 に示し た。なおグラフの数值は, 未加熱試料を100とした場合 の加熱試料の熱安定性を示している。アビエビエと柳葉 の水抽出物は, 加熱時間に関係なくほぼ同様の抗酸化性 を示した。バヤム・エム, アビエビエのエタノール抽出 物と, バイアム, ナイロビ茎葉のエーテル抽出物は, 加 熱時間の延長に伴い, 抗酸化性が上昇する傾向を示した。 
しかし, ナイロビ茎葉の水抽出物の抗酸化性は, 急激に 低下した。

\section{5．アマランサス抽出物の $\mathrm{pH}$ 安定性}

アマランサス抽出物の各 $\mathrm{pH}$ における抗酸化力の安定 性について，ロダン鉄法による測定結果を Fig.4 に示し た。なおグラフの数值は，未加熱試料を100とした場合 の加熱試料の $\mathrm{pH}$ 安定性を示している。アビエビエと柳 葉の水抽出物は, 塩基性では抗酸化性がやや低下したが, その他の条件下では抗酸化性を示した。ナイロビ茎葉の 水抽出物は, いずれの条件下でも特に強い抗酸化性を示 した。

\section{6.ラジカル捕捉活性試験}

Fig.5に，コントロールを100とした場合のラジカル 捕捉活性を示した。アマランサス抽出物は, エタノール 抽出物を除く 8 種にラジカル捕捉活性を認め, Trolox が51に対して, 水抽出物ではアビエビエが 7 , 柳葉が 18 , ナイロビとK40各茎葉が 29 と 16 , エーテル抽出物では バイアムが39, 農研セ91-3, K4, ナイロビの各茎葉が それぞれ29，41，49と強い抗酸化力を示した。

\section{7. 肉団子の油脂の酸化抑制度}

肉団子調製時にアビエビエ, 柳葉, ナイロビ茎葉の水 抽出物, アビエビエ, 柳葉の水抽出物にクエン酸を, ア ビエビエ, 柳葉の水抽出物と, アビエビエのエタノール 抽出物に $\alpha$ ートコフェロールを混合したものを添加し， 加熱処理した肉団子計 8 種をコントロールと比較検討し た。クエン酸， $\alpha$-トコフェロールの使用濃度は， 4 . の(3)と同様とした。これらの保存期間中の POVの変化 をFig.6に示した。保存開始から 2 週間が経過すると, 肉団子の変敗度にわずかな差が生じ始め, コントロール とナイロビ茎葉の水抽出物を添加した肉団子は，27日以 降急激に POVが上昇した。しかし，アビエビエや柳葉 の水抽出物を添加した肉団子の POV は緩やかな上昇に とどまり,アビエビエや柳葉の水抽出物にクエン酸, $\alpha$ ートコフェロールを混合して添加した肉団子では, 更に POVの変化は少なかった。なかでも柳葉の水抽出物に クエン酸， $\alpha$-トコフェロールを添加した肉団子は，40 日経過後で $20 \mathrm{mgeq} / \mathrm{kg}$ 以下を示し, 強い抗酸化力を示 した。

\section{考察}

アマランサス抽出物の抗酸化性を, 最終的に食品加工 へ利用するための基礎的知見を得ることを目的として実 験を行った。そこで, 最初にアマランサス抽出物が他の 抗酸化性物質と相乗効果を示すかどうかについて検討し
た。その結果, アビエビエと柳葉の水抽出物は, リノー ル酸モデル系に扔いて, クエン酸, $\alpha$-トコフェロール との相乗効果を示し, 肉団子への添加試験においても抗 酸化効果を認めた。クエン酸は, 一般に脂質過酸化を促 進する金属イオンを封鎖することにより抗酸化性を発現 するが，特にフェノール性の抗酸化性物質との間に著し い抗酸化的相乗効果を示すことが知られている20)。従っ て, アビエビエと柳葉の水抽出物中には, フェノール性 物質が含をれている可能性は高いと推察される。アビエ ビエと柳葉の水抽出物は, その他の条件下においても比 較的安定な抗酸化性を示したことから, 天然抗酸化性物 質として食品加工への応用が十分可能と考えられる。

またラジカル反応は連鎖反応であり，これを防止する には連鎖を切断するための抗酸化性物質, いわゆるラジ カル捕捉活性を有する物質の共存が望をしい。ラジカル 捕捉活性は, グローブ, オールスパイス等15種類のスパ イスや加熱処理された野菜類に見られる11)。アマランサ ス抽出物の加熱処理, $\mathrm{pH}$ の調整, 調理過程での影響に ついては今後の検討課題と考える。またアマランサスの 抗酸化活性成分の本態については, 現在検討中である。

\section{要 約}

食用アマランサス 12 種，17部位のエタノール抽出物を リノール酸メチルを基質とした油系に抢いて抗酸化能ス クリーニングを行ったところ，15部位（ラルシャーク， バヤム・エム, バヤム・ピイ, アビエビエ, 丸葉, 柳葉, バイアムと, メキシコ, ナイロビ, 農研セ91-3, K4, 赤穂の各茥葉とメキシコ, ナイロビ, K4の各子実）に 非常に強い抗酸化効果が認められた。

（1）抗酸化力試験に打いて，強い抗酸化性を示したも のは, アビエビエ, 柳葉, ナイロビ茎葉の水抽出物, バヤム・エムとアビエビエのエタノール抽出物, バ イアムとナイロビ茎葉のエーテル抽出物の 7 種であ った。

(2) クエン酸と相乗効果を示したものは, アビエビエ と柳葉の水抽出物であり， $\alpha$-トコフェロールと相 乗効果を示したものは, アビエビエと柳葉の水抽出 物とアビエビエのエタノール抽出物であった。

（3） $100{ }^{\circ} \mathrm{C} 120$ 分までの加熱に対して安定性を示したも のは,ナイロビ茎葉の水抽出物を除く 6 種であった。

（4） $\mathrm{pH}$ に対する安定性では, アビエビエ, 柳葉, ナ イロビ茎葉の水抽出物が安定性を示し, なかでもナ イロビ茎葉の水抽出物は，いずれの $\mathrm{pH}$ においても 非常に強い安定性を示した。 


\section{日本食生活学会誌}

（5）アマランサス抽出物のラジカル捕捉活性は，非常 に強く, 水抽出物のアビエビエ, 柳葉, ナイロビと $\mathrm{K} 4$ の茎葉の 4 種と, エーテル抽出物のバイアムと ナイロビ, 農研セ91-3, K4の各茎葉の 4 種, 計 8 種に認められた。

（6）肉団子の酸化安定性には, アビエビエと柳葉の水 抽出物が効果を示し, クエン酸や $\alpha$-トコフェロー ルとの混合では, 基礎実験の結果と同様な相乗効果 を示し，保存期間の延長をもたらした。

\section{参考文献}

1）ナショナル・アカデミー・サイエンス編 : 21 世紀の熱帯植 物資源，楽游書房，p.16，(1983）

2）三宅妙子，松本義信，根岸由紀子，奥崎政美，菅原龍幸： 日本食生活学会誌，9(4)，45（1999）

3）三宅妙子, 奥崎政美, 山口文芳, 菅原龍幸 : 日本食生活学 会誌，8 (2)，52（1997）

4）三宅妙子，根岸由紀子，奥崎政美，佐々木弘子，菅原龍幸： 日本食生活学会誌, 10(1)，57(1999)

5）三宅妙子：川崎医療福祉学会誌，4，121（1994）

6）能勢征子，藤野直子：日食工誌，29，507（1982）

7）春日敦子, 青柳康夫, 菅原龍幸: 日食工誌, 35,828
(1988)

8）春日敦子，青柳康夫，菅原龍幸 : 日食工誌，40，56（1993）

9）津田孝範，藤井正人，渡邊美栄，中莖秀夫，大島克己，大 澤俊彦，川岸舜明：日食工誌，41，475（1994）

10）津田孝範, 深谷吉則, 大島克己，山本 明，川岸舜明，大 澤俊彦：日食工誌，42，430（1995）

11）山口智子，林恵里奈，藤本さつき，高村仁知，的場輝佳： 日本食品科学工学会第45回大会講演集, 社日本食品科学工学 会, p.67 (1998)

12）中村泰郎：今月の農業，33，34（1989）

13）佐柄一男, 阿部 弘: 東北農業研究，44，239（1991）

14）内藤茂三, 山口直彦，横尾良夫：日食工誌，28，291 (1981)

15）日本油化学協会編：基準油脂分析試験法，2.4.12-86 (1972)

16）満田久輝, 安本教傳, 岩見公和：栄養と食糧, 19, 210 (1966)

17）市川朝子, 藤井 聡, 河本正彦：日食工誌，22，159 (1975)

18) Yamaguchi, T., Takamura, H., Matoba, T. and Terao, J.: Biosci. Biotechnol. Biochem., 62, 1201 (1998)

19）菅原龍幸編：食品学実験書, 建帛社, p.58-59, p.117-123 (1995)

20）太田静行：油脂食品の劣化とその防止，幸書房，p.135 (1977) 